\title{
PHYSIOLOGICAL AND BIOCHEMICAL RESPONSE OF BROILER CHICKENS TO AMINO ACIDS ADMINISTRATION
}

\author{
Ebtsam Sh.A. Bakry ${ }^{1^{\star}}$, El-Shahat ${ }^{1}$ N., El-Hady ${ }^{1}$ S. and El-Wardany ${ }^{2}$ I.
}

1- Biochemistry Dept., Fac. of Agric., Ain Shams Univ., P.O. Box 68, Hadayek Shubra 11241, Cairo, Egypt

2- Poultry Production Dept., Fac. of Agric., Ain Shams Univ., P.O. Box 68, Hadayek Shubra 11241, Cairo, Egypt

*Corresponding author: ebtsam.bakry134@gmail.com

Received 2 November, 2019

Accepted 11 December, 2019

\section{ABSTRACT}

The main objective of this study was to evaluate the effect of amino acids supplementation to drinking water of meat-type broiler chickens on their blood parameters and productive traits. A total of sixty one day old, unsexed broiler chicks were obtained from a local hatchery. They were divided into three treatment groups: control group, and two treatment groups supplemented (via drinking water) with amino acids preparation (Amino2500 USA Premium Nutrition) at 0.5 and $1.0 \mathrm{~g} / \mathrm{L}$, respectively. All chicks were fed a commercial low protein diet containing 19\% crude protein and 2900 kcal metabolizable energy per kilogram of the diet. Chicks of the control group was fed the recommended (standard) diet containing $23 \%$ crude protein and $3000 \mathrm{kcal}$ of $\mathrm{ME} / \mathrm{Kg}$. The duration of the experiment was five weeks. The criteria of productive and physiological responses were live body weight, weight gain, blood plasma protein fractions, plasma lipids (cholesterol, triglycerides, high density lipoprotein (HDL) and low density lipoprotein (LDL). Transaminase (ALT and AST) activity indicative of liver function was measured. Kidney function test in terms of plasma creatinine, urea nitrogen and uric acid were also determined. Results showed that live body weight and weight gain of broiler chickens were significantly increased by AA administration either at three or five weeks of age. At marketing age (5 weeks), birds from the $3^{\text {rd }}$ and $2^{\text {nd }}$ groups achieved heavier body weigh by 32.3 and $26.8 \%$ more than the control chickens. Blood plasma total protein, albumin and globulin levels were significantly increased in the AA treatment groups for T3 and T2, respectively as compared to the control chicks. Addition of AA resulted in an obvious increase in the activity of ALT and AST indicative of negative influence of excess AA on livers function-related enzymes, especially with the higher dose of AA (T3). This was also observed for plasma uric acids and creatinine concentrations as end products of protein metabolism. The histological sections from lymphoid organs revealed better histological appearance indicative of better immunity and bird's health. It is concluded that excessive AA administration for broilers fed on low protein diet, could be used to increase live body weight, enhance protein metabolism without negative impacts on blood biochemistry, and improve their immune response. However, further study is needed to assess the cost and the net revenue from AA supplementation.

Keywords: Amino acids, Live body weight, Blood constituents, Broiler chicks

\section{INTRODUCTION}

In Egypt, the excessive demands for poultry meat and egg play a very important role in providing well- balanced foods, in terms of good animal protein sources for human consumption. However, the feeding cost of poultry production is generally the most expensive item (65-70)\%, particularly the unit of protein . Results obtained by many investigators showed that protein utilization was improved by minimizing excess levels of essential amino acids (AA) in the diet (Parr and Summers, 1991, Holsheimer and Janssen, 1991; 1994; Deschepper and DeGroote, 1995). In practice it is very difficult to formulate diet with natural feed ingredients that well provide all AA needed by chicks in adequate quantities and to maintain an optimal 
AA balance with minimal excesses (Jensen and Colnago, 1991). Recent advances in commercial production of crystalline $A A$ make several in dispensable AA (Inn) more economically feasible for use in animal and poultry feeds (Jensen and colnago, 1991). In this concern, earlier study by Deschepper and DeGroote (1995) demonstrate that it is possible to obtain the same final live body weight of broiler chicks by seeding low protein diets supplemented with synthetic essential and nonessential AA. Torne et al (2016) concluded that optimization of CP in the diet of commercial broiler through provision of supplementary amino acids could enhance profits of broiler breeders. Also, Nasr and Kheiri (2017) and Reis et al (2018) suggested that diet formulation based on digestible amino acids with addition of $L$ - lysine at the level of $110 \%$ of NRC in starter and grower diets optimized body weight gain in Arain male broilers. However, recent investigations declared that $A A$ supplements to broiler chicks many has some physiological effects in blood constituents related to protein metabolism and both liver and kidney function responses (Petrilla et al 2018 and Erwan, 2018). More recently, Mwaniki and Kiarie, (2019) stated that ileal digestibility (SID) of amino acids (AA) lysine, methionine, cysteine, threonine, isoleucine, and valine was $86.3 \%, 88.7 \%, 72.8 \%, 85.5 \%$, $89.6 \%$, and $88.6 \%$, respectively.

Therefore, the main objective of the present study was to elucidate the effect of supplementing AA on productivity and some blood biochemical parameters of broiler chicks.

\section{MATERIALS AND METHODS}

The present study was conducted in the Poultry Physiology lab, Faculty of Agriculture, Ain Shams University, Egypt. The main objective was to evaluate the effect of amino acids supplementation to drinking water of meat-type broiler chickens on their blood parameters and productive traits. A total of 60 day old, unsexed broiler chicks were obtained from a local hatchery. They were divided into three treatment groups as follows: the first group was kept as a control group, while the 2nd and 3rd groups were supplemented (via drinking water) with amino acids preparation (Amino-2500 USA Premium Nutrition) at 0.5 and $1.0 \mathrm{~g} / \mathrm{L}$, respectively. All chicks were fed a commercial low protein diet containing $19 \%$ crude protein and $2900 \mathrm{kcal}$ metabolizable energy per kilogram of the diet. Chicks of the control group was fed the recommended (standard) diet containing $23 \%$ crude protein and $3100 \mathrm{kcal}$ of $\mathrm{ME} / \mathrm{Kg}$ according to National Research Council (NRC) (1994). Chicks of all groups were kept under similar hygienic and managerial conditions. Feed and water were provided ad libitum, while a lighting program of $22 \mathrm{~h}: 2 \mathrm{~h}$ (light to dark) was applied. The duration of the experiment was four weeks (from the 2nd to the 5th week of age).

\section{Blood samples}

Blood samples were collected from 6 chicks at the beginning of the experiment ( 7 days) and then at the end of the growing period (5 weeks of age). Blood was collected in heparinized tubes, centrifuged at $4000 \mathrm{rpm} / \mathrm{min}$, then plasma was decanted and stored frozen- at $20^{\circ} \mathrm{C}$ until the biochemical analysis were done. The criteria of response were plasma total protein, albumin, transaminases activity (AST and ALT), uric acid and creatinine. All measurements were done by using available commercial kits (Spectrum Comp. for Diagnostic kits, Cairo, Egypt. Thyroid hormones assay was done by RIA technique according to Britton et al (1975) while IGF-1 was determined according to Houston and O.Neill (1991) Productive performance traits in terms of live body weight and weight gain, were also recorded during the whole experiment period.

\section{Histological study}

At the end of the experiment, representative tissue samples from different lymphoid organs (bursa of Fabricius, thymus and spleen) were taken at slaughtering time to study the histological changes associated with the experimental treatments. Samples were fixed in a $10 \%$ formalinsaline solution before preparing the histological slices by using Paraffin technique where, specimens were dehydrated in ascending grades of ethanol, cleared in Zylene and then embedded in paraffin wax. Transverse sections (4-5microns, thick) were cut, mounted on glass slides and then stained with haemotoxyline and eosin (H\&E) stains according to methods described by Culling, (1983). All sections were examined by using an electric light microscope provided with computerized Camera.

\section{Statistical analysis}

Data were subjected to one way analysis of variance by the general linear model procedure (GLM) of the statistical analysis system (SAS, 2001). Difference between mean were detected by Duncan's multiple range and $F$ test (Duncan, 1955). 

acids administration

\section{RESULTS AND DISCUSSION}

\section{a- Effect of amino acids (AA) on growth per- formance of broilers}

Live body weight (LWB) and body weight gain (BWG) of broiler chicks as influenced by AA supplementation to drinking water are presented in Table (1).

It is clear from the results that the initial LBW of chicks was nearly similar at the beginning of the treatments indicative of random distribution of chicks in different treatments. On the other hand, there were significant differences between groups in LBW at three and five weeks of age. The best values were recorded for chicks received T3 treatment compared by those received T2 treatment, respectively. Compared to birds of the control group, this increase reached to $32.3 \%$ and $26.8 \%$ for chickens from T3 and T2 at the age of marketing (5 wks). A similar trend was also observed for BWG, where birds in T2 and T3treatment groups had significantly higher gain than the control group during all experiment periods and for the whole time (1d-5wk) as shown in Table (2). These results indicate that $A A$ supplementation to could enhance (LBW) of chicks at marketing age, which mean that more poultry meat, with expected benefits to producers. Also, it may be an increase in AA content of meat which benefits consumer, as healthy food. Moreover, the physiological response of broiler chicks to AA addition was clearly noticed in terms of an increase in plasma total protein, albumin, globulin and $A / G$ ratio. This increase was significantly higher for chicks of T2 and T3 groups compared to the control one (Table 3).

One the other hand, the addition of AA resulted in an obvious increase in the activity of ALT and AST indicative of negative influence of excess $A A$ on livers function-related enzymes, especially with the higher dose of AA (Table 4). This was coincident with progressive increases in uric acids, urea and creatinine concentrations as end products of protein metabolism in birds.

\section{Histological observations}

\section{1- Bursa of Fabricius}

The histological examination of bursa sections from different treatments indicated that the basic histological structure of the bursal tissues is nearly similar in all treatments (Fig. 1-3).
In general, the bursa of Fabricius is a primary lymphoid organ in birds. It is composed of about 15 - 20 plicae (folds) each of them contain numerous follicles (f) with various sizes (tall or short). These follicles have two distinct areas, i.e. cortex (C) and medulla (M) enclosed in a pseudostratified columnar epithelial outer layer (e) as shown in all sections, especially Fig. (2 and 3). They were separated from each other by fine connective tissue septa (S), while their secretions are collected in lumens (L). Section clearly showed that the cortex is more deeply stained than the medulla because it composed of many small lymphocytes, whereas the medulla appeared as a pale-stained area containing large lymphocytes, undifferentiated epithelial cells (d) and lymphoblasts. This structure was clearly observed in bursa section from both $A A$ treatments (Fig. 2, 3). The effect of AA administration revealed positive impacts on bursa histology, in terms of increased the number of follicles / microscopic field, along with a narrow connective tissue septa (S) between follicles compared by chicks from the control treatments. It is of interest to observe that the improved histological appearance of bursal follicles in response to $A A$ treatments, especially as shown in Fig. (3), was associated by an obvious increase in the cortex area with apparently better and well -developed epithelium covering (e) of the whole plicae area. It appears that $A A$ exerts beneficial effects on bursal function via its effect on promoting immunoglobulins secretion as the number of B- lymphocytes increased.

Our results are in close agreement with the findings by Akter et al (2006); who reported a strong correlation between the relative size of bur$\mathrm{sa}$, its histological structure and the average level of $\operatorname{lgG}$ production, so the maintenance of functional B-lymphocytes.

\section{2-Thymus histology}

The histological structure of thymus gland as affected by different treatments is illustrated in Fig. 4 to 6 .

In general, the gland is enclosed by a thin connective tissue capsule of coarse collagen fibers and few elastic fibrils. There are many fine septa (s) that divide the gland to several thymic lobules (L) differing in their size and shape. In addition each thymic lobule is composed of outer- darkstained areas cortex (c) area and a pale region located in the lobules center or merged in the cortex area (medulla, M). It is clearly observed that 
Table 1. Effect of Amino acids supplementation to drinking water on live body weight $(\mathrm{g})$ of broiler chickens at different ages

\begin{tabular}{|c|c|c|c|c|}
\hline Treatment & day old & One week & 3 weeks & 5 weeks \\
\hline T1 & $45.33 \pm 2.62$ & $118.33 \pm 6.40$ & $505.00^{\mathrm{c}} \pm 25$. & $1653.33^{\mathrm{c}} \pm 49.6$ \\
T2 & $45.56 \pm 2.68$ & $113.29 \pm 8.03$ & $694.00^{\mathrm{a}} \pm 19.5^{\mathrm{a}}$ & $2096.67^{\mathrm{a}} \pm 81.8$ \\
T3 & $45.18 \pm 3.57$ & $114.42 \pm 6.35$ & $676.67^{\mathrm{a}} \pm 35.2$ & $2186.67^{\mathrm{a}} \pm 68.1$ \\
\hline Sig. & NS & NS & $* *$ & $* *$ \\
\hline
\end{tabular}

$a, b, c:$ Means within columns with different superscripts are significantly different $(p \leq 0.05)$.

T1: control, T2: $0.5 \mathrm{~g} / \mathrm{L}$ AA , T3:1.0 g/L AA

Table 2. Effect of amino acids supplementation to drinking water on body weight gain (g) of broiler chickens at different ages

\begin{tabular}{|c|c|c|c|c|}
\hline Treatment & $\mathbf{1 d} \mathbf{- 1}$ week & $\mathbf{1}-\mathbf{3}$ weeks & $\mathbf{3} \mathbf{- 5}$ weeks & $\mathbf{1 d - 5}$ weeks \\
\hline T1 & $73.13 \pm 3.24$ & $386.57^{\mathrm{b}} \pm 12.35$ & $1148.16^{\mathrm{c}} \pm 41.20$ & $1607.48^{\mathrm{c}} \pm 72.18$ \\
T2 & $67.71 \pm 4.16$ & $580.66^{\mathrm{a}} \pm 23.17$ & $1402.59^{\mathrm{b}} \pm 62.13$ & $2050.77^{\mathrm{b}} \pm 84.30$ \\
T3 & $69.21 \pm 3.54$ & $562.18^{\mathrm{a}} \pm 19.65$ & $1510.62^{\mathrm{a}} \pm 54.73$ & $2141.28^{\mathrm{a}} \pm 78.32$ \\
\hline Sig. & NS & $*$ & $* *$ & $* *$ \\
\hline
\end{tabular}

$a, b, c$ : Means within columns with different superscripts are significantly different ( $p \leq 0.05)$. T1: control, T2: $0.5 \mathrm{~g} / \mathrm{L}$ AA , T3:1.0 g/L AA

Table 3. Plasma protein fractions of broiler chicks as affected by amino acids supplementation to drinking water

\begin{tabular}{|c|c|c|c|c|}
\hline \multirow{2}{*}{ Treatment } & TP & ALB & Globulin \\
$\mathbf{g} / \mathbf{d l}$ & $\mathbf{g} / \mathbf{d l}$ & $\begin{array}{c}\text { A/G ratio } \\
\mathbf{g} / \mathbf{d l}\end{array}$ \\
\hline T1 & $0.18^{\mathrm{b}} \pm 3.97$ & $2.34 \pm 0.10^{\mathrm{c}}$ & $1.63 \pm 0.06^{\mathrm{b}}$ & $1.44 \pm 0.04$ \\
T2 & $6.15 \pm 0.98^{\mathrm{a}}$ & $3.52 \pm 0.26^{\mathrm{b}}$ & $2.63 \pm 0.05^{\mathrm{a}}$ & $1.34 \pm 0.05$ \\
T3 & $6.75 \pm 1.06^{\mathrm{a}}$ & $3.93 \pm 0.42^{\mathrm{a}}$ & $2.82 \pm 0.07^{\mathrm{a}}$ & $1.40 \pm 0.05$ \\
\hline Sig. & $* *$ & $*$ & $*$ & NS \\
\hline
\end{tabular}

$a, b, c$ : Means within columns with different superscripts are significantly different ( $p \leq 0.05)$. T1 : control , T2 : 0.5g/L AA, T3:1.0 g/L AA 

acids administration

Table 4. Liver and kidney function indicators of broiler chicks as affected by amino acids supplementation to drinking water

\begin{tabular}{|c|c|c|c|c|c|}
\hline \multirow{2}{*}{ Treatment } & $\begin{array}{c}\text { ALT } \\
\mathbf{U} / \mathbf{L}\end{array}$ & $\begin{array}{c}\text { AST } \\
\mathbf{U} / \mathbf{L}\end{array}$ & $\begin{array}{c}\text { Uric acid } \\
\mathbf{m g} / \mathbf{d l}\end{array}$ & $\begin{array}{c}\text { Urea } \\
\mathbf{m g} / \mathbf{d l}\end{array}$ & $\begin{array}{c}\text { Creatinine } \\
\mathbf{m g} / \mathbf{d l}\end{array}$ \\
\hline T1 & $22.86 \pm 2.06^{\mathrm{c}}$ & $49.65 \pm 3.20^{\mathrm{b}}$ & $11.84 \pm 2.56^{\mathrm{b}}$ & $0.52 \pm 0.02^{\mathrm{c}}$ & $0.66 \pm 0.04^{\mathrm{c}}$ \\
T2 & $38.90 \pm 4.55^{\mathrm{b}}$ & $60.18 \pm 5.63^{\mathrm{a}}$ & $12.2 \pm 2.66^{\mathrm{b}}$ & $0.64 \pm 0.02^{\mathrm{b}}$ & $0.82 \pm 0.03^{\mathrm{b}}$ \\
T3 & $54.6 \pm 3.86^{\mathrm{a}}$ & $62.69 \pm 5.82^{\mathrm{a}}$ & $15.6 \pm 2.73^{\mathrm{a}}$ & $0.78 \pm 0.03^{\mathrm{a}}$ & $1.09 \pm 0.06^{\mathrm{a}}$ \\
\hline Sig. & $* *$ & $*$ & $*$ & $*$ & $*$ \\
\hline
\end{tabular}

$a, b, c$ : Means within columns with different superscripts are significantly different $(p \leq 0.05)$.

$\mathrm{T} 1$ : control, T2 : 0.5g/L AA, T3:1.0 g/L AA

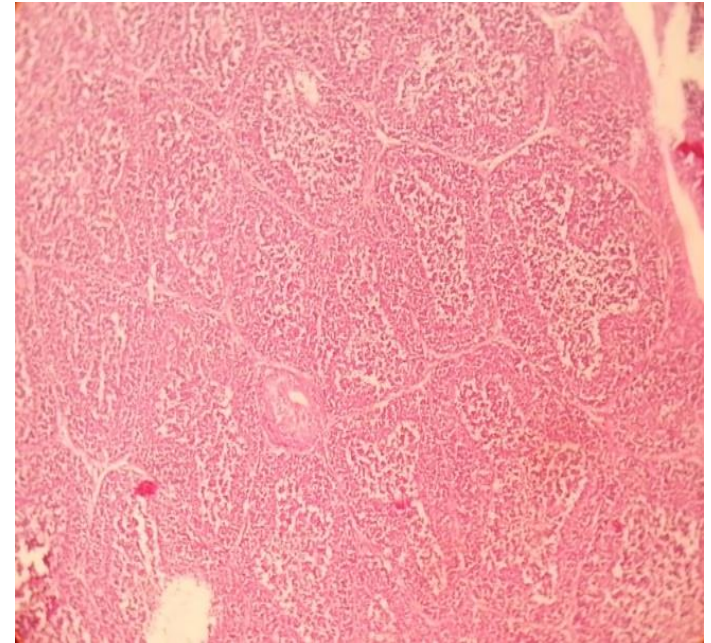

Fig .1. T.S. through bursa of Fabricius from chicks of the control treatment (H\&E x 100).

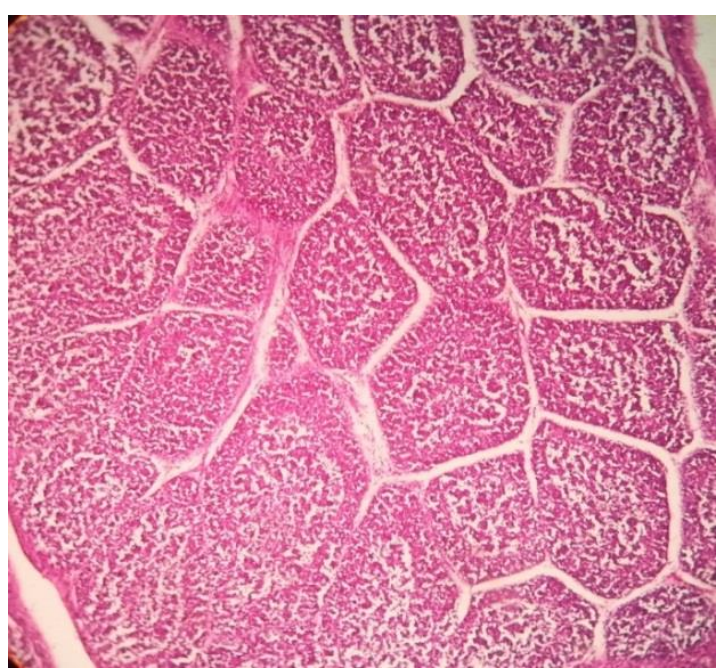

Fig. 2. T.S. through bursa of Fabricius from chicks of $\mathrm{T} 2$ treatment $(\mathrm{H} \& \mathrm{E} \times 10)$

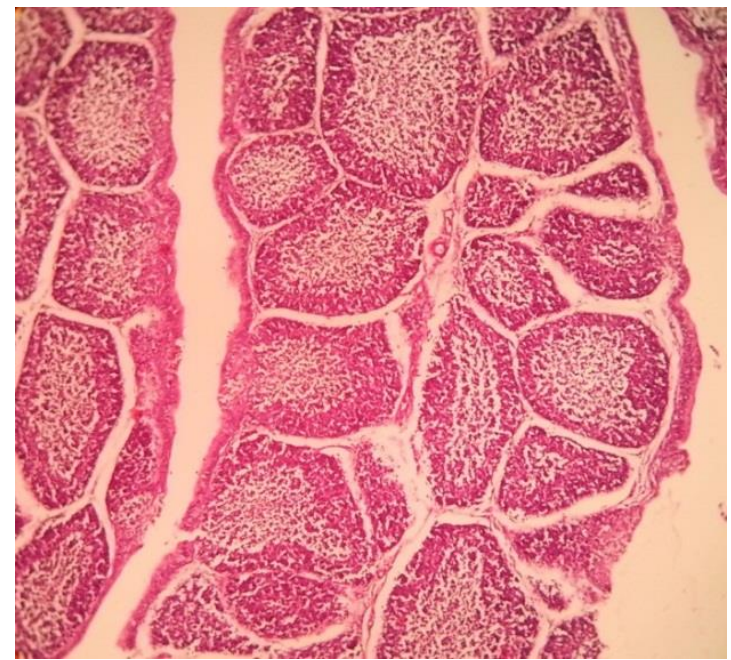

Fig .3. T.S. through bursa of Fabricius from chicks of T3 treatment (H\&E x 100$)$.

the cortex area contains many small and large lymphocytes (Ly) especially in the section of chicks from the AA- treated groups of chickens (Fig. 5 and 6). While, section from control chicks (Fig. 4) showed little response to the applied treatments, in terms of their thymus histological architecture. This may be resulted from the fact those chicks had better bursa histological appearance which may support the well- known findings that the immune response of chicks at older ages depends mainly on B- lymphocyts production (Bursal - origin), than T-lymphocytes from thymus glands. This was confirmed by the results obtained by Akter et al (2006) and more recently by Khan et al (2014) who discussed the developmental changes of lymphoid organs in chickens. So, it is likely that the effect of in ovo injection of different iron forms during embryogenesis, caused less prominent histo- 
logical changes in thymus gland, unlike the bursa of Fabricius. This may be resulted from the fact those chicks had better bursa histological appearance which may support the well- known findings that the immune response of chicks at older ages depends mainly on B - lymphocyts production (Bursal - origin), than T-lymphocytes from thymus glands. This was confirmed by the results obtained by Akter et al (2006) and more recently by Khan et al (2014) who discussed the developmental changes of lymphoid organs in chickens. In this concern, our results, however, showed an obvious improvement in the histological appearance of thymus gland in response to different the two $A A$ levels.

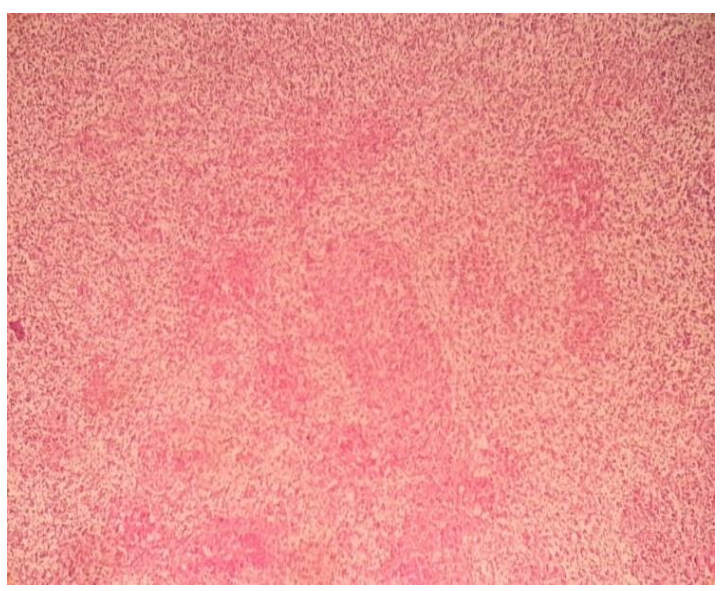

Fig. 4. T.S. through thymus from chicks of the control treatment $(H \& E \times 100)$

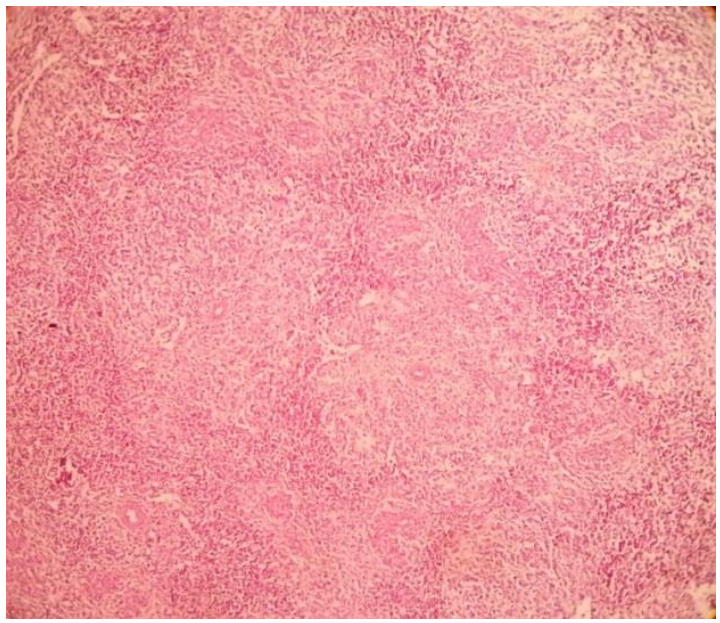

Fig .5. T.S. through bursa of Fabricius from chicks of the $\mathrm{T} 2$ treatment $(\mathrm{H} \& \mathrm{E} \times 100)$

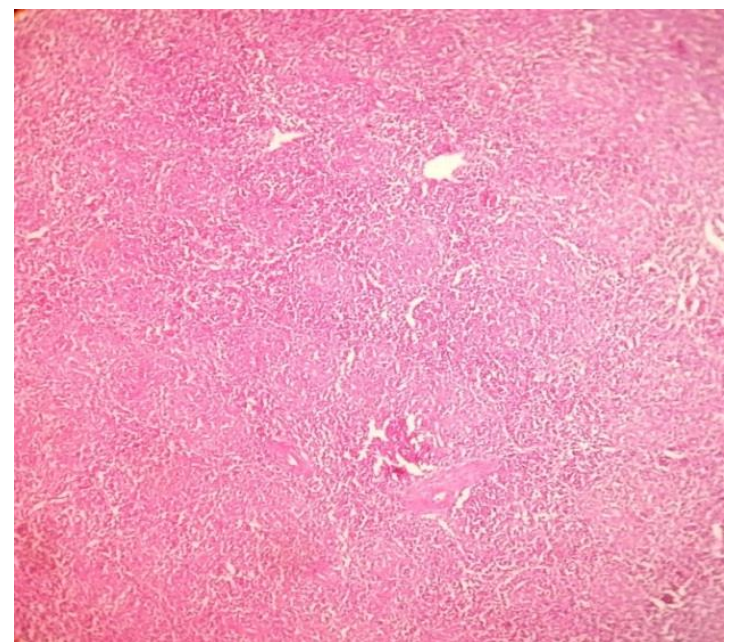

Fig. 6. T.S. through thymus from chicks of the T3 treatment (H\&E x 10)

\section{3- Spleen histology}

The histological structure of the spleen as influenced by AA administration to broiler chicks is illustrated in Fig. (7 to 9). It is clear from these sections that the basic architecture of spleen from different treatments has nearly similar structure, in which two main regions could be seen, i.e. a large white pulp area (WP) and a dark - stained red pulp area (RP) with numerous blood capillaries, sinusoids (S) and many lymphocytic cells of different sizes and numbers along with more or less lymphatic nodules. This was observed in the spleen section from the control groups (Fig. 7). The same pattern was also observed in the spleen sections from AA treatments (Fig. 8; 9) but an increase in the RP area could be seen. Moreover, there were an irregular distribution of the RP area within the WP one, especially in the sections from chicks of the inorganic (Fig. 17) and organic iron (Fig.18) treatments. Since, the RP area is extended all over the spleen sections with a marked increase in the number of large lymphocytes accompanied by basophilic hemosiderin granules in between the blood sinusoids. These large -sized lymphocytes may reflect an improvement in immune response of chicks from these treatment groups. In this respect, spleen in considered as a secondary lymphoid organ in birds, and it was reported by many authors to be the main site of lymphocytes proliferation and differentiation (Hodges, 1974). The impact $A A$ treatments in enhancing the histological structure of spleen in our study is evidenced by the presence of many lymph nodules ( $n$ ) which resembles the lymph nodes in mammals. These lymphat- 

acids administration

ic nodules (follicles) have been reported to be directly related to better immunity of birds. Thus, there is evidence that the spleen of birds harbour large numbers of T-cells and B-cells which differentiate into antigen - specific effector cells. This concept was confirmed by the previous results by John (1994), Powers (2000); Sato et al (2004). It is assumed that the spleen, as a secondary immune organ in birds, has lesser sensitivity to the effect of $A A$ administration than the primary immune organs (bursa and thymus). This assumption emphasized the results of Compton et al (1990) who showed that organs where lymphocytes are stored, being less sensitive to the effect of different stressors. Also, Ardia (2005) stated that larger spleens provide stronger immunity as measured by $\mathrm{PHA}$ responsiveness test.

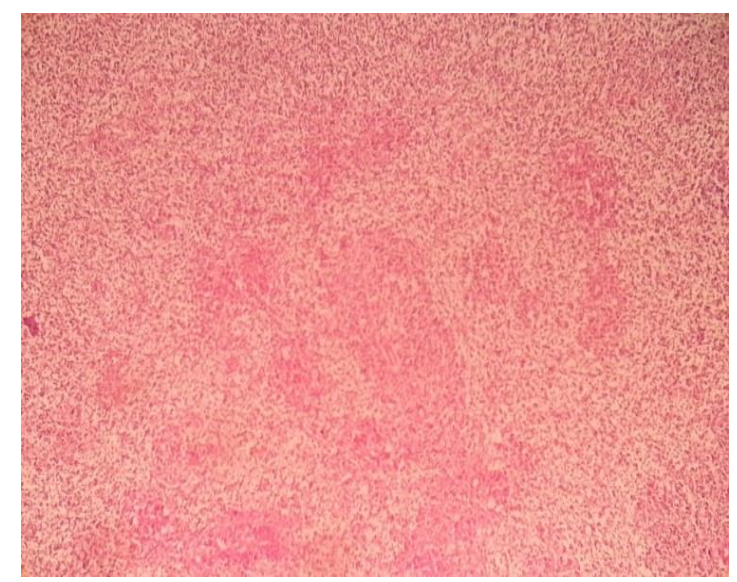

Fig. 7. T.S. through spleen from chicks of the control treatment $(\mathrm{H} \& \mathrm{E} \times 10)$

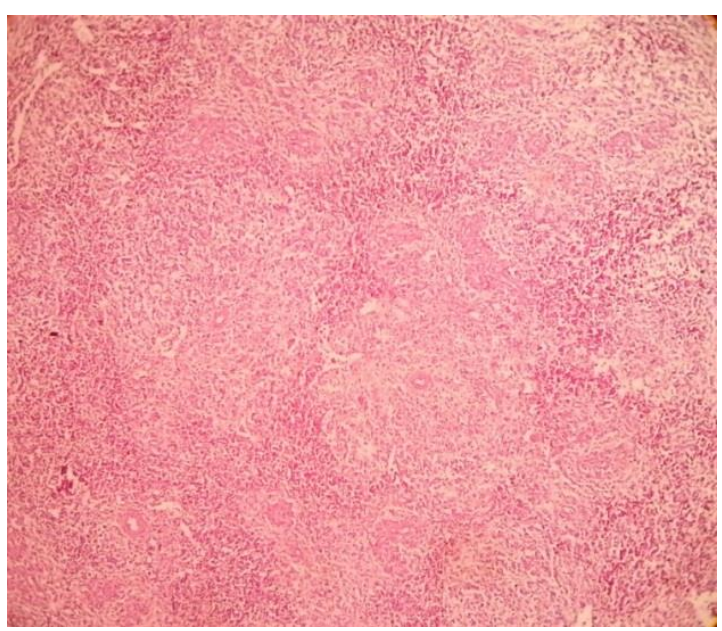

Fig. 8. T.S. through spleen from chicks of the $\mathrm{T} 2$ treatment $(H \& E \times 10)$.

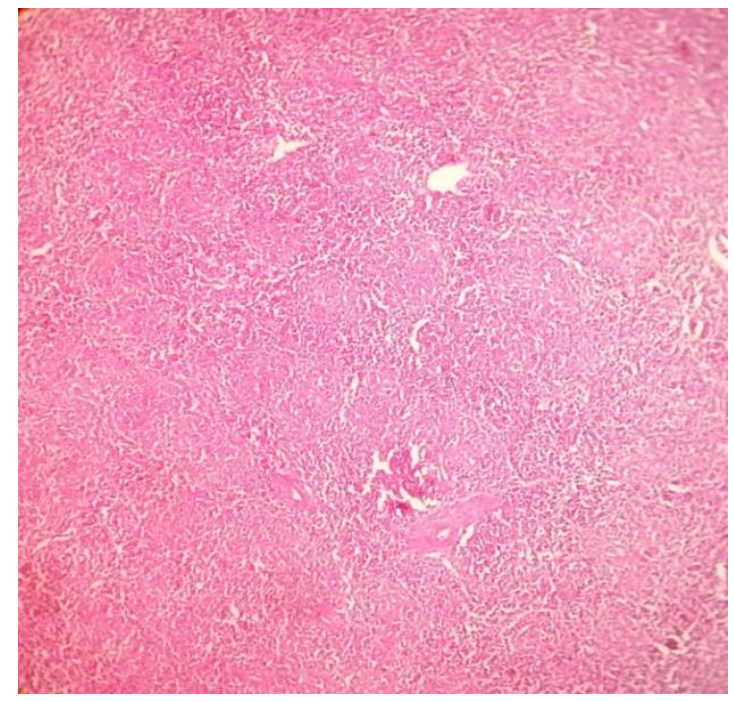

Fig. 9. T.S. through spleen from chicks of the T3 treatment (H\&E x 10).

It is concluded that AA administration for broilers fed on low protein diet, could greatly increase their (LBW) and enhance protein metabolism with minor effects on liver function-related enzymes. The histological sections from immunity - related lymphoid organs revealed better histological appearance indicative of better immunity and bird's health.

\section{REFERENCES}

Britton K.E., Quin V.C., Brown B.L. and Edkins R.P. 1975. A strategy for thyroid function tests. Brit. Med. J. III, pp. 350-356.

Culling C.F. 1983. Handbook of Histopathological and Histochemical Staining Technique. $3^{\text {rd }}$ Ed. Butterworths, London, UK, pp. 322345.

Deschepper K. and Degroote G. 1995. Effect of dietary protein, essential and non-essential amino acids on the performance and carcass composition of male broiler chickens. Br Poult. Sci., 36, 229-245.

Duncan D.B. 1955. Multiple range and multiple $F$ tests. Biometrics. 11, 1-42.

Erwan E. 2018. Supplementation of caloric- and protein-restricted diets with L-leucine stimulates food intake and improves carcass characteristics in broiler chickens. Int. J. of Poultry Sci. 17(1), 28-33. 
Holsheimer J.B. 1994. Response of broiler chicks to threonine-supplemented diets to 4 weeks of age. Br. Poultry Sci., Sep., 35(4), 551-562.

Holsheimer J.P. and Janssen W.M.M.A. 1991. Limiting amino acids in law protein maize soybean meal diets fed to broiler chicks from 3 to 7 weeks of age. Br. Poultry Sci., 32, 151158.

Houston B. and O.Neill I.E. 1991. Insulin and growth hormone act synergistically to stimulate insulin - like growth factor -1 production by cultured chicken hepatocytes. J. Endocrinol. 128(3), 389-393.

Jensen L.S. and Colnago G.L. 1991. Amino acids and protein for broilers andlaying hens. In: proceedings Maryland nutrition conference for feed manufactures. Baltimore, MD., USA, pp. 29-36.

Mwaniki Z.N. and Kiarie E. 2019. Standardized ileal digestible amino acid and apparent metabolizable energy content in defatted black soldier fly larvae meal fed to broiler chickens. Canadian J. of Anim. Sci., 55(6), 241-250.

Nasr J. and Kheiri F. 2017. The effect of formulation diets based on digestible amino acids and lysine levels on carcass and chemical composition of broiler. Iranian J. of Applied Animal Sci., 7(2), 313- 320.
National Research Council 1994. Nutrient Requirements of Poultry. $9^{\text {th }}$ revised Ed. National Academy press, Washington, DC., USA.

Petrilla A., Matis G., Kulcsar A., Talapka P., Biro E., Mackei M., Febel H. and Neogrady Z. 2018. Effect of dietary cereal type, crude protein and butyrate supplementation on metabolic parameters of broiler. Acta Veterinaria Hungarica , 66(3), 408-425.

Reis M., Sakomura N.K., Teixeira I.A.M.A., da Silva, Edney P. and Kebreab E. 2018. Partitioning the efficiency of utilization of amino acid in growing broiler: Multiple linear regression and multivariate approaches. PLoS One, 13(12), 360-369.

Statistical Analysis Systems 2001. SAS/STAT® User's Guide. Version 8.2, SAS Institute, Cary (NC), USA.

Torne D.J., Bade R.N. and Deshmukh S.V. 2016. Optimization of dietary protein level through amino acids balancing on performance and economics of commercial broiler chicken production. Indian J. of Animal Nutrition, 33(4), 471-474. 


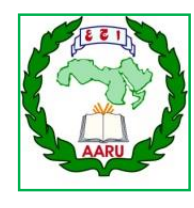

مجلة اتحاد الجامعات العربية للعلوم الزراعية، جامعة عين شمس، القاهرة، مصر مجلا(27)، عدد(5)، 2479-2487، 2019

Website: http://ajs.journals.ekb.eg

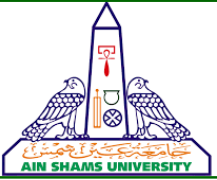

2487

الإستجابة الفسيولوجية وإلكيميائية الحيوية لإعطاء الأحماض الأمينية لاجاج اللحم

[196]

$$
\begin{aligned}
& \text { ابتسام شعبان أحمد بكري1" - نجاح الثحات1 - سمير الهادي1 - (براهيم الورداني2 }
\end{aligned}
$$

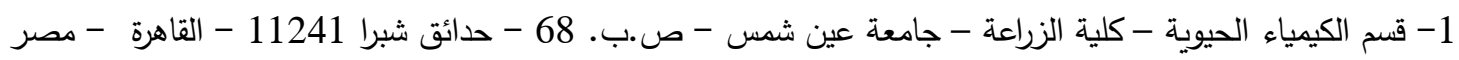

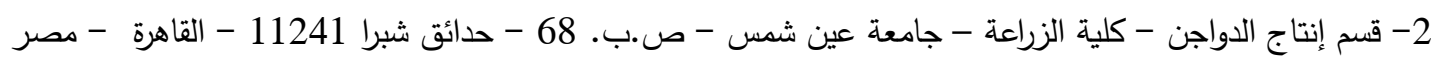

*Corresponding author: ebtsam.bakry134@gmail.com

Received 2 November, $2019 \quad$ Accepted 11 December, 2019

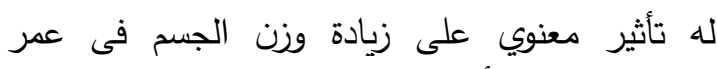

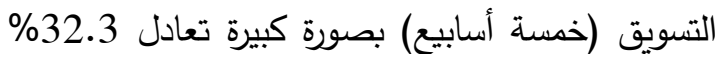

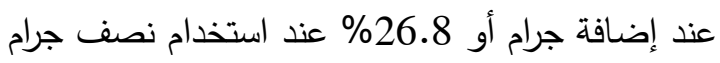

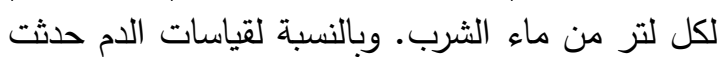

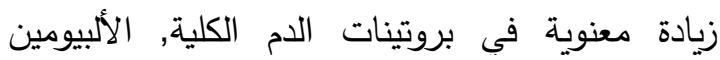

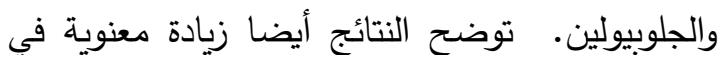

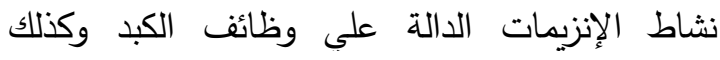
قياسات الدم المرتبطة بوظائف الكلى وظلى مثل الئل اليوريا,

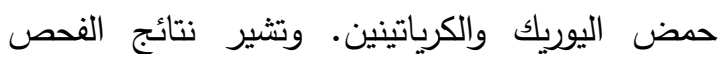
الهستولوجى للجهاز المناعى في الدواجن إلى حدئي حدوث

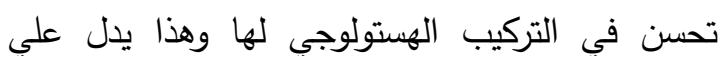

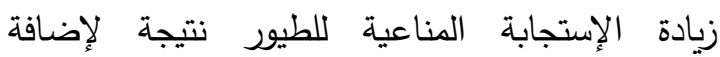
الأحماض الأمينية. - الجانة

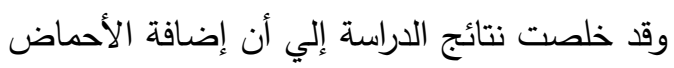

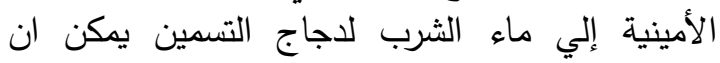

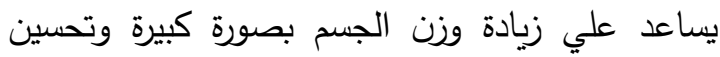
مناعة الطيور دون تأثيرات سلبية علي كيمياء الدام, لأبراء ولكن الموضوع يحتاج للمزيد من الأدراسة لمعرفة دائة

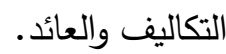

الكلمات الدالة: الأحماض الأمينية، دجاج اللحم، وزن

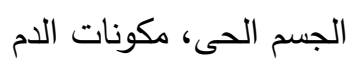

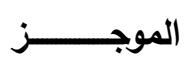

كان الهدف من هذه الدراسة تقييم التأثيرات الناتجة

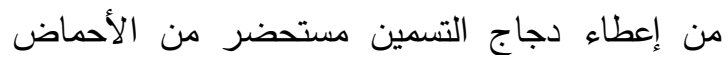

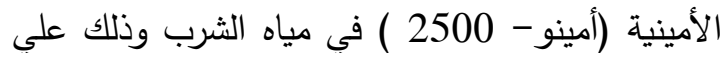

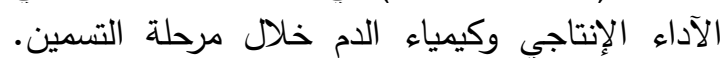
ولتحقيق هذا الهدف تم استخدام عدد 60 كتكوت

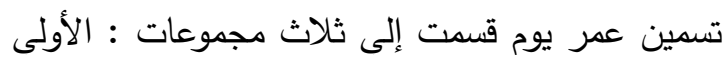
للمقارنة, الثانية تم إضافة نصف إلى جرام من الأحماض

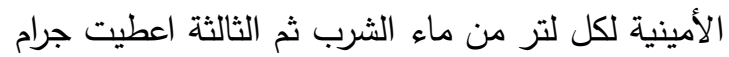
لكل لتز. تم تغذية كتاكيت المجموعة الأولى لتي على الثي

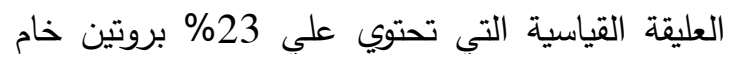

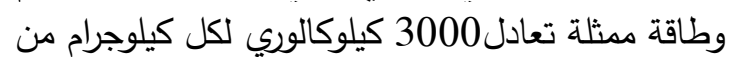
العليقة, أما كتاكيت المجموعتان الثانية والثالثة فقد كادئ

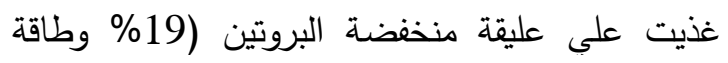

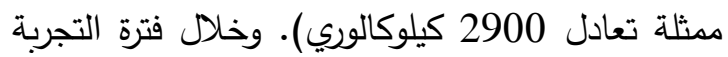

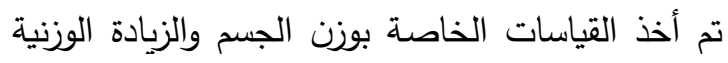
كما تم تقدير بعض مكونات الدم مثل البروتين الكلي, الإني

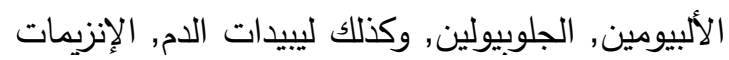

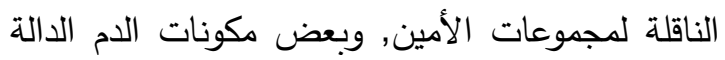

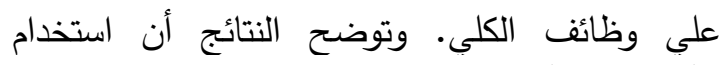
الأحماض الأمينية كمكمل غذائي لاجاج التسمين كان 